\title{
Professores DO ENSINO SUPERIOR FRENTE ÀS NOVAS TECNOLOGIAS: USOS E DESUSOS DO COMPUTADOR E DA INTERNET NO COTIDIANO DE TRABALHO
}

\author{
Reivani Chisté Zanotelli
}

O atual panorama educacional e econômico vem sendo moldado por duas poderosas forças: tecnologia e informação. A sucessora da sociedade industrial - a sociedade de informação - penetra e molda quase todos os aspectos da vida diária. Todas as categorias profissionais são, de alguma forma, afetadas e o professor de Ensino Superior não fica de fora deste processo. A partir da fala dos professores concluiu-se que o uso dos recursos da Tecnologia da Informação está cada vez mais difundido no meio acadêmico, mas que ainda estamos vivendo em uma fase de transição.

\section{BANCA:}

Bernardo Jablonski (Orientador)

Adriana Benevides Soares

Carlos Americo Alves Pereira

Cílio Rosa Ziviani

Maria Alice Magalhães D’Amorim

Data da defesa: 20/03/2009 